\title{
Imagination and Memory in Marsilio Ficino's Theory of the Vehicles of the Soul ${ }^{1}$
}

\author{
Anna Corrias \\ The Warburg Institute \\ annacorrias_8o@hotmail.com
}

\begin{abstract}
The ancient Neoplatonic doctrine that the rational soul has one or more vehiclesbodies of a semi-material nature which it acquires during its descent through the spheres - plays a crucial part in Marsilio Ficino's philosophical system, especially in his theory of sense-perception and in his account of the afterlife. Of the soul's three vehicles, the one made of more or less rarefied air is particularly important, according to Ficino, during the soul's embodied existence, for he identifies it with the spiritus, the pneumatic substance based in the brain which was believed to serve as an instrument for perception and imagination. He refers to the vehicles in his arguments against the theory of the transmigration of souls into the bodies of animals, claiming that the imaginative suffering experienced after death by souls in their aerial bodies are much more acute than the physical pain they might feel in bodies made of flesh and blood. Since the power of the imagination, for Ficino, is stronger than that of the four senses, the soul's perceptive activity is more intense after death, when it has lost its earthly body and lives instead in a body made of air. The vehicles, moreover, provided Ficino with evidence for the individual immortality of souls, a doctrine that he was attempting to demonstrate philosophically against the position of Averroes and his followers. In his view, the vehicles ensured the survival after death of two faculties which were intimately connected to personal identity: the imagination and memory. By pointing out the role of the
\end{abstract}

1) This work has been made possible thanks to a bursary funded by the RAS (Regione Autonoma della Sardegna) together with the PO Sardegna of the European Social Fund 2007-2013-L.R.7/2007 Promozione della ricerca scientifica e dell'innovazione tecnologica in Sardegna.

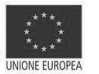

(C) Koninklijke Brill NV, Leiden, 2012

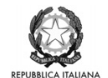

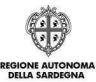

DOI: $10.1163 / 187254712 X 620988$ 
vehicles in transporting the soul's innermost representations and memories through the universe, Ficino was able to show that the distinguishing traits of our personality are not lost with bodily death, but survive along with the vehicle that carries them.

\section{Keywords}

Ficino, Plotinus, vehicles of the soul, metempsychosis, immortality, spiritus

\section{Marsilio Ficino and the Theory of the Vehicles of the Soul}

Marsilio Ficino (1433-1499) is one of the most influential figures in the history of Neoplatonic philosophy. He played a major role in the rediscovery of ancient Neoplatonic works in the fifteenth century and in the reception of Neoplatonism in early modern philosophy. In addition to translating Plato's works into Latin and providing many of them with commentaries, Ficino produced Latin versions of Porphyry's On Abstinence, Synesius's On Dreams, Iamblichus's On the Mysteries of the Egyptians, Chaldeans, and Assyrians and Plotinus's Enneads. With regard to Plotinus, Ficino's translation and interpretation shaped the view which European scholars and philosophers had of the late ancient Neoplatonist up to the nineteenth century. It has long been recognized that his translation, while philologically accurate and often remarkably astute in solving a number of obscuri loci in the text, rested on a particular interpretation of the Enneads. In appropriating Plotinus's philosophy for his own purposes, which were centered on demonstrating the agreement between Platonism and Christianity, Ficino placed great emphasis on the special mediating role of the human soul, linking the world of the intellect to that of nature. ${ }^{2}$ In doing so, he helped to efface Plotinus's original preoccupation with the ineffable nature of the One. More significantly, however-and this feature of Ficino's interpretation is of the utmost importance for understanding the later reception of Platonism in Europe, before Jacob Brucker, Wilhelm Gottlieb Tenneman and, in particular, Friedrich Schleiermacher-his account of Plotinus's philosophy was deeply imbued with elements characteristic of post-Plotinian Platonism such as demons, spirit and theurgy,

\footnotetext{
2) See, however, M. J. B. Allen (1982), which shows that Ficino did not always put the human soul in the centre of his hierarchy of being.
} 
in which Iamblichus, above all, but also Synesius, Psellus and even PseudoDionysius played a distinctive hermeneutical role.

The theory of the vehicles of the soul, with which this paper is concerned, is one of the post-Plotinian doctrines that Ficino introduced into his interpretation of the Enneads. As is well known, the vehicle of the soul, called ochêma in Greek, was regarded as an inner body, neither material nor immaterial, which the soul acquired in its descent from the intelligible world to the earth and which acted as tertium quid between spirit and matter. ${ }^{3}$ Although Eastern influences had a crucial role in the shaping and evolution of this theory, the most important sources for the concept of a semi-corporeal body of the soul were Plato and Aristotle. ${ }^{4}$ Plato described a sort of vehicle which accompanies the soul in its descent to the earth, both during its embodied life and even in Hades. In Timaeus 41e1-2 we read that the Demiurge 'distributed each [soul] to each [star], and having mounted them [human souls] as if on a vehicle, he showed them the nature of the universe'. A passage in the Phaedo (113b4-6) suggests that the vehicle is also important for the soul's afterlife: 'Those who seemed to have lived in a middle course travel to Acheron, ascend onto their vehicles, and arrive at the lake on them. ${ }^{5}$ Moreover, the myth of the chariot in the Phaedrus (247b1-3) was also interpreted in terms of vehicles of the charioteer-souls. While Plato seems to be responsible for creating the concept of a vehicle which guides the soul from the gods to earth, the ochê$m a$ 's most important function, as the dwelling place of the faculty of the imagination, depends on Aristotle's theory of the pneuma as the seat of the lower soul, analogous to the element out of which the stars are made. ${ }^{6}$ Later philosophers combined these Platonic and Aristotelian passages in order to create an entity which, in keeping with the Neoplatonic view of

3) On the ochêma in ancient Neoplatonsim see R. C. Kissling (1922), Appendix II in E. R. Dodd's edition of Proclus (1933), J. Bidez (1964), J. M. Dillon (1973), A. Smith (1974), J. F. Finamore (1985) and M. Di Pasquale Barbanti (1988). On the ochêma as an intermediary between the earth and the higher levels of reality see G. Verbeke (1945), 309.

4) The Eastern origin of the theory, accepted by most scholars, was contested by Dodds, who maintained that the concept of the ochêma was created entirely within the circle of Greek philosophy and that Eastern forms of astral mysticism influenced the application rather than the substance of the theory. See Proclus (1933), 314, n. 1.

5) See J. F. Finamore (1985), 2.

6) Aristotle, De generatione animalium, $736 \mathrm{~b} 37-38$. 
the cosmos as a manifestation of divine energy, could bridge the gap between the noetic and the earthly worlds. The number of vehicles varied from author to author: sometimes it was one, as in Porphyry; sometimes two or more, as in Proclus. Interpretations of the substance and the fate of the vehicles also differed: after the death of the earthly body, the vehicle was said to remain in the intelligible world either for a certain time or forever. There was, nevertheless, general agreement as to the vehicle's metaphysical role, which was to enable the soul to become embodied, that is, to descend from the Intellect (Nous), unconfined by either time or space, to the world of generation, which, by contrast, was defined by the limitations of time and space.

Since, however, Plotinus maintained that rational souls did not descend, remaining united to the universal Intellect, in his philosophy they did not need the vehicle as a means of travelling to the earth. As a result, the doctrine of the ochêma is almost absent from his thought or, at any rate, not systematically developed. It was only with later authors that the theory was fully worked out and found a place within the corpus of Neoplatonic doctrines. Yet, despite this, Ficino used the post-Plotinian vehicles to explain some important passages of the Enneads concerning, for instance, metempsychosis and the nature of after-death memory. The doctrine of the ochêma is fundamental both to Ficino's metaphysics and to his theory of knowledge. His account of the soul's vehicles is, however, complicated and often keyed to particular texts. This is in part due to his constant efforts to avoid positions which were unacceptable to Christian theology such as the pre-existence and transmigration of souls, two assumptions that were implicit in the doctrine. ${ }^{7}$

Nevertheless, as Michael Allen and James Hankins have both noted, Ficino was fascinated by, and wrote extensively about, the idea that the soul has both an ethereal and an airy vehicle which exist before the earthly body comes into being and which survive its corporeal death. ${ }^{8}$ Intriguingly, Ficino used this heterodox doctrine as evidence both against the theory of the soul's transmigration into the bodies of animals and in support of the Christian belief in the immortality of the individual soul.

\footnotetext{
7) See D. P. Walker (1958), 39. For a dissenting view, see M. J. B. Allen (2008a) and (2008b): Allen argues that Ficino was in fact drawn to some of these heretical views.

8) See J. Hankins (2005), 5 and M. J. B. Allen (2008a).
} 
With regard to transmigration, Ficino tried to demonstrate that, from a metaphysical standpoint, it was impossible for rational souls to change their species from human into animal and that, therefore, this theory was not only heretical, but also philosophically unsustainable. Claiming that those ancient Platonic thinkers who discussed metempsychosis into animals bodies were speaking 'poetically', rather than putting forward a real belief, he introduced the ochêma to show that transmigration was only possible from the corporeal body to the vehicle and vice versa or from one vehicle to another. To back up this position, he adduces several arguments which prove that human souls are more severely punished for their earthly sins in a body made of air than in an animal body. ${ }^{9}$

As for the belief in the immortality of individual souls, this was a topic very dear to Ficino's heart. It played a key role in his attempts to 'Platonize' Christianity, which, in his view, had been corrupted by those who tried to interpret it by relying exclusively on the principles of Aristotle's natural philosophy. He was particularly keen to counter the position of contemporary philosophers who followed the teachings of Aristotle's medieval Arabic interpreter Averroes, especially his notion of the 'unity of the agent intellect', which implied that there was only one rational soul for all mankind, thus ruling out individual immortality. According to Averroes, separate forms or substances continued to exist, after death, in the common active intellect of the human species; so immortality was possible, but only in a purely impersonal sense. In the fifteenth century, Averroes's philosophy was very popular in some Italian universities, especially the University of Padua, a bastion of Aristotelianism. Here the presence of philosophers such as Nicoletto Vernia, who openly maintained that the immortality of the individual soul was contrary to Aristotelian philosophy, attracted the attention of the bishop of Padua. On 4 May 1489, he issued a decree entitled 'Edictus contra disputantes de unitate intellectus' (Edict against those who debate the unity of the intellect), which prohibited the discussion of this topic outside universities. ${ }^{10}$ For the Christian Platonist Ficino, the position of Averroes and his fifteenth-century commentators on the soul was a dangerous challenge to the Christian

\footnotetext{
9) On Ficino and transmigration see J. Hankins (2005) and B. Ogren (2004). See also M. J. B. Allen (2001), 159-178.

10) See P. F. Grendler (2004), 283-84.
} 
belief in individual immortality. ${ }^{11} \mathrm{He}$ was therefore particularly concerned to prove that the soul's survival after death involved the entire person and not merely the forms of his or her intellectual knowledge. To underline this point, he refers to the vehicles as the place where both the images perceived and the memories acquired during our earthly life were imprinted and then stored. ${ }^{12}$ Since the vehicles survived bodily death, so, too, did the contents of our imagination and our memories, all of which are unique to us and make us distinct from any other person. As we shall see, in his Commentary on Plotinus Ficino maintains that images and memories remain in the vehicle, awaiting the return of the rational soul. ${ }^{13}$ The vehicle therefore performed a vital function in his case for the personal immortality of the soul, ensuring the survival of the individual self in its entirety, not merely of the forms of its intellectual knowledge.

Despite the important part which the vehicles of the soul played in Ficino's philosophy, he was often inconsistent about their number: sometimes there seem to be four but at other times three. Scholars analyzing Ficino's interpretation of this doctrine have pointed out the complex nature of his pneumatology. ${ }^{14}$ Michael Allen, in particular, has helped to clarify his views on the number and function of vehicles. For the purposes of this paper, however, the following outline will be sufficient. According to Ficino, the soul has a celestial, an airy and a vaporous vehicle, in addition to the earthly body. The celestial vehicle is acquired in the highest region of the heavens and is made of pure fire. It is shaped like a planet, but it transforms itself into our angular human form when it enters the earthly body. ${ }^{15}$ In his Commentary on Enneads II.2, he briefly discusses

11) See book XV of his Platonic Theology, especially chs 12, 13, 14 and 17, in M. J. B. Allen and J. Hankins, Platonic Theology (hereafter PT), V, 135-170 and 189-202. On Ficino and Averroes see M. J. B. Allen (2010). On Averroistic philosophy in Italy during the Renaissance, see P. O. Kristeller (1965), 111-18; D. Iorio (1991), E. Coccia (2005), 22-27 and J. Hankins (2005).

12) See later, 12-13.

13) See later, 22-23.

14) M. J. B. Allen (1989), 168-204; I. P. Coulianu (1981), 360-408 and 391-397; R. Klein (1970), 69-86; P. O. Kristeller (1988), 403-405; B. Ogren (2004), 63-94 and 64-79; D. P. Walker (1958), 119-150; B. Tambrun (1999), 43-48 and S. Toussaint (2007).

15) Ficino, PT, VI.18.4, 103: 'Hoc vocant Magi vehiculum animae, aethereum scilicet corpusculum acceptum ab aethere, immortale animae indumentum, naturali quidem figura rotundum propter aetheris regionem, sed in humanam effigiem sese transferens quando 
which motion is to be ascribed to the fiery vehicle, in both its embodied and after-death life, and compares its swiftness to the agility of the eye, which moves rapidly from one image to another. After posing the question of whether our two bodies-the inner one, that is, the celestial vehicle, and the outer one-follow the circular motion of the soul, he replies:

The solid and compound body does not do so at all, since its motion is rather rectilinear, either because all elements within it are outside their natural place or because it is carried, by its needs, towards external objects. Our celestial body, which is hidden within us, adapts its circular shape to the shape of the earthly body-into which it was introduced from the beginning —and, when it exits from here, it will immediately recover its circular shape. Meanwhile, however, its circular motion is in some way hindered: while it bears a human shape, it can only try and act with all its might; but as soon as the soul leaves its earthly body, that extremely swift body is agitated in a similar manner by any command whatever of the soul. This body is like the eye of the soul, but it is whirled round more easily by any of the soul's commands than our eye is by an act of the visual power. ${ }^{16}$

This passage makes it clear that, according to Ficino, the first vehicle, since it is of a heavenly nature, represents the first actualization of the soul's inner motions, which it reproduces with the maximum efficiency and fidelity. During its descent towards the earth, however, this vehicle tends to acquire new layers from the spheres through which it passes, until it produces a second vehicle, mainly composed of air. This vehicle is, in turn, enveloped by a third veil, thicker and mistier, made up of the

corpus humanum ingreditur atque in priorem se restituens cum egreditur.' Ficino makes significative references to the theory of the soul's vehicles also in his commentary on Plato's Phaedrus. See M. J. B. Allen (1981), 77, 99, 127 and 149.

16) Ficino, Commentary on Plotinus, in Opera Omnia, 1607: 'Corpus quidem solidum et compositum id minime facere, quia potius moveatur in rectum, tum quoniam quae in eo sunt, extra locum sunt posita naturalem, tum quoniam ob indigentiam trahitur ad externa. Corpus vero caeleste, quod est in nobis occultum, orbicularem sui figuram ad figuram terreni corporis, cui insinuatum est, ab initio redegisse, quum hinc exierit eam subito recepturum. Interea vero orbicularem motum quodammodo impediri posse: quinetiam tentari pro viribus atque agi, quatenus fert corporis terreni figura; at quum primum anima terrenum exit corpus, quolibet animae nutu corpus illud agilissimum similiter agitari. Est etiam quasi quidam animae oculus, sed facilius animae nutu rotatur, quam oculus noster visualis virtutis aspectu.' 
vapors from the bodily humors. As Ficino explains in his Platonic Theology:

Many Platonists think that the soul uses three vehicles: first the immaterial and simple, i.e., the celestial vehicle, second the material and simple, i.e., the airy vehicle and third the material and compound, which is the vehicle formed by the four elements. To the first the soul gives an irrational but immortal life, to the second an irrational but lasting life, which survives for some time in the simple body after the compound body has dissolved. To the third vehicle, finally, the soul gives an irrational life which will dissolve together with the dissolution of the body. ${ }^{17}$

This fourfold scheme can be simplified if we consider that elsewhere Ficino speaks of the soul as having, not four, but three bodies, treating the airy vehicle as the intermediary between the ethereal and the earthly bodies. ${ }^{18}$ Therefore, we can assume that he understood the airy vehicle and the vaporous spirit, not so much as two separate bodies, but as one and the same substance, although in different states of rarefaction. ${ }^{19}$ While the fiery vehicle is only indirectly involved in the perceptual activity of the embodied soul, the airy and body-oriented vehicle-whether single or twofold - takes on a crucial role during the soul's life on earth, for it is connected, although not explicitly, to the vaporous and hot substance based in the brain and flowing throughout the human body by means of the nervous system, known during the Renaissance by the name of spiritus. $^{20}$ The spiritus was understood to be the link between the rational soul and the living body: the element which enabled communication between the soul's higher and lower faculties. It was through the spiritus, according to Ficino, that the soul governed and animated the body. Moreover, the spiritus retained the images which were perceived by the soul and on the basis of which it elaborated new representations. It therefore played a

\footnotetext{
17) Ficino, $P T$, VI.18.5, 111.

18) See, e.g., Ficino, $P T$, III.10.2, 130: 'Neque tamen carni infunditur primum, sed mediis ducitur competentibus, ut Magi Persarum docent. Primo quidem in ipso descensu coelesti aëreoque involvitur corpora, deinde spiritu ex corde genitor, qui in nobis coeli instar temperatissimus est, et lucidissimus. His mediis corpora clauditur crassiore.'

19) See M. J. B. Allen (1989), 179.

20) See P. O. Kristeller (1988), 406.
} 
fundamental role in the way each soul came into contact with the external world and in both its retention of memories and its elaboration of images. For this reason, the spiritus was closely connected to the formation of personal identity, although at a pre-intellectual level. The analogy between the spiritus and the soul's vehicle has often been suggested. ${ }^{21}$ However, it is a topic which still awaits exploration. In the next section I shall refer to some passages which might help us to understand the nature of this analogy.

\section{The Vehicle of the Soul and Ficino's Notion of spiritus}

The idea of the spiritus as an intermediary between the incorporeal and the corporeal dimensions of the cosmos can be traced back beyond ancient Neoplatonic philosophy to Aristotelianism, Galenic medicine and Stoicism. ${ }^{22}$ According to Aristotle, the pneuma was a corporeal substance which acted as an instrument of the incorporeal soul. It was the agent of bodily vitality and had two essential roles: on the one hand, it helped join the soul to the body; on the other, since it was analogous in nature to the elements of which the stars were made, its presence within the body was interpreted to insure a permanent connection between human beings and celestial bodies. ${ }^{23}$ In Galenic physiology, the pneuma was the principle of life, originating from the 'world spirit' and corresponding to the soul's astral body. ${ }^{24}$ These medical doctrines might have influenced the Stoics, who made the pneuma the most important principle of both their cosmological and psychological theories. They regarded the pneuma as a luminous body similar in nature to fire, which permeated the universe and gave life to plants, animals and human beings. Human souls were considered to be a spark of this divine principle, which made it possible for biological processes, such as reproduction, and psycho-physiological activities, such as sense perception, to take place. After death, the pneuma was said

\footnotetext{
21) See, e.g., D. P. Walker (1958), 123; B. Ogren (2004), 76 and P. O. Kristeller (1988), 406.

22) See C. Allbutt (1921), 224-264.

23) Aristotle, De generatione animalium, 736B-737A.

24) Galen, De placitis Hippocratis et Platonis, in Opera omnia, Basel 1538, V, 643. See D. P. Walker (1984), 225.
} 
to ascend to the sublunary region and to remain there for a certain time before merging into the 'world spirit' from which it came. Stoic pneumatology influenced the Renaissance notion of spiritus, both directly (through the rediscovery of Stoic works) and indirectly through the medical and other philosophical writings in which it could be found. ${ }^{25}$ Together with ancient Neoplatonic theories of the soul's vehicles, it may have contributed to the fifteenth-century idea of the spiritus as an intermediary between macro-cosmos and micro-cosmos, as the element by which the human soul was connected to higher levels of reality, serving as the gateway both for the operations of demons and for astrological influences. At the same time, it was regarded as the instrument by which the soul vivified the body and which was responsible for motor activity, sense perception and the lower activities of the imagination.

In Ficino's writings, the spiritus occupies a prominent position. Indeed, his speculations on the physiological aspects of the spiritus and the role which it plays in medicine, magic and natural philosophy constitute an almost exhaustive account of Renaissance pneumatology. He writes: "The spiritus is defined by the physicians as a certain vapors of the blood, pure, subtle, hot and lucid' and that 'it is formed by the subtler blood by the heat of the heart, flies to the brain, and there the soul assiduously employs it for the exercise of both the interior and the exterior senses. Thus the blood serves the spirit, the spirit the senses, and finally the senses reason. ${ }^{26}$ The fact that the spiritus, as understood by Ficino and by his contemporaries, was a corporeal substance which originated in the blood and depended on a specific bodily organ - the heart — might lead us to think that is was a different entity from the soul's vehicle, which, by contrast, existed before the earthly body. Ficino, moreover, was always very cautious about suggesting a correspondence between human spirits and the soul's spiritual body. There are, nonetheless, indications that, for him, the airy vehicle and the spiritus were one and the same substance or, at least, fulfilled identical functions. First, the spiritus was made out of the same material as the second vehicle: air which had been breathed and vapors arising from the bodily humors. Second, Ficino defines spiritus as the

${ }^{25)}$ On Stoicism in the Renaissance see J. Kraye (2004); P. Barker (1991); B. Joly (1993).

${ }^{26)}$ Ficino, Three Books on Life, I.2, in Opera omnia, I, 496, tr. by D. P. Walker (1983), 3. See also PT II.7.6, 235 and III.9.5, 57-59. 
element which links the immaterial soul to the material body and which has the same attributes as the ochêma of the Neoplatonists: tenuousness, transparency and an intermediate nature:

As the true philosophy teaches us, the soul, since it is most pure, is linked to this gross and earthy body, which is so different from it, only by means of a superlatively fine, transparent, diminutive body which we call the spirit. ${ }^{27}$

In another passage from his Platonic Theology, he refers to (Pseudo-)Alexander of Aphrodisias, who called the element that linked the soul and the body either 'spirit' or 'vehicle', in the manner of the Platonists. ${ }^{28}$ Most importantly, in the same work, Ficino goes so far as to define the spiritus as the vehicle of the soul (currus animae), referring explicitly to the ochêma of Porphyry, Iamblichus and Synesius. ${ }^{29}$ As noted by D. P. Walker, Synesius, in particular, may have influenced the way in which Ficino connects-more or less explicitly-human spirits with the soul's vehicle. ${ }^{30}$ Synesius had clearly identified the spiritus, which he defined as pneuma phantastikòn in Greek, with the ochêma that descended from the heavens to the earth: it was the soul's first instrument and the subject of the activity of the imagination..$^{31}$ This connection between the spiritus, the imagination and the soul's vehicle is undoubtedly present in Ficino, who invoked Synesius several times in his De vita coelitus comparanda, a work devoted to the care of the spiritus. ${ }^{32}$ Furthermore, he translated Synesius's On Dreams into Latin around 1488; and, in this translation, the imagination, which Synesius located in and identified with the pneuma, was described as the first body of the soul. ${ }^{33}$

\footnotetext{
27) Ficino, $P T$, II.7.6, 235.

28) Ficino, PT, V.15.1, 10. See (Pseudo)Alexander of Aphrodisias, Problemata medica 2 prologus (ed. Ideler, p. 53).

${ }^{29)}$ Ficino, PT, III.9.5, 58: 'Sed spiritus qui est animae currus, a corporibus quibusque pulsatur'.

30) See D. P. Walker (1958), 39.

31) Synesius, On Dreams, VII.

${ }^{32)}$ Ficino, Three Books on Life, in Opera omnia, I, 531, 538, 562.

33) Synesius, On Dreams, tr. by Ficino, in Opera omnia, II, 1971: 'Spiritus phantasticus est primum animae vehiculum.'
} 
Another text which may have encouraged Ficino to make a connection between the spiritus and the soul's vehicle is George Gemistus Pletho's Commentary on the Chaldean Oracles. Ficino owned a copy (contained, together with Synesius's On Dreams, in MS Riccardianus graecus 76) and was, no doubt, familiar with this work, ${ }^{34}$ in which the pneuma is presented as corresponding to the ethereal body of the soul (the only vehicle in Pletho's system). ${ }^{35}$ Unlike Pletho, Ficino, as we have seen, believed that there were two or three vehicles; nevertheless, he might have retained Pletho's idea, while associating the spiritus with the airy, rather than the fiery, vehicle. This seems to be suggested by his explicit reference to the Chaldean Oracles in the Platonic Theology:

Yet the soul does not at first mingle with the flesh: it is brought down through the appropriate intermediate stages, as the Persian Magi teach. First, in the actual descent, it is enveloped in a celestial body of air and afterwards in a spirit generated from the heart, which in us is perfectly tempered and dazzling bright like heaven. With these as intermediaries, it is enclosed in the coarser body. ${ }^{36}$

The spiritus is described here as the vessel which receives the fiery vehicle when the soul becomes embodied and which contains it during its existence on earth, an image used elsewhere to refer to the external body. ${ }^{37}$ The spiritus and the soul's airy vehicle are identified, as if the latter was a kind of physical accretion acquired by the soul and by its fiery vehicle as a consequence of their new earthly life.

Another aspect of Ficino's notion of spiritus suggests an analogy with the soul's vehicle: its adaptability to the forms of our imagination. According to Ficino, the function of the imagination is not limited to representing

34) For the Latin translation of Pletho's Commentary on the Chaldean Oracles, formerly ascribed to Ficino, see P. O. Kristeller (1984), 120. On Ficino and the Chaldean Oracles see B. P. Copenhaver (1987); I. Klutstein (1984) and B. Tambrun-Krasker (1999).

35) Chaldean Oracles no. 14. On Pletho's commentary see Tambrun-Krasker (1995), 10-12. See also R. Cudworth III (1995), III, 271: 'Thus Pletho declares their [of the ancient assertors of the soul's immortality] sense: "By this ethereal body is our soul connected to its mortal body; the whole thereof being implicated with the whole vital spirit of the embryo, forasmuch as this itself is a spirit also."'

${ }^{36)}$ Ficino, PT, III.10.2, 131.

37) Ficino, PT, IV.13.4, 204. See P. O. Kristeller (1988), 406. 
images of sensible objects to the soul, but it also influences and modifies bodily matter to such an extent that we can fall ill and recover by means of the images of illness and healing we have in our mind. Ficino compares this imaginative power to the Greek sea god Proteus, who was able to take on many different forms: the faculty of imagination, he says, is manycolored like a chameleon and therefore capable of giving ever-changing appearances to the forms it produces ${ }^{3}{ }^{8}$ The less solid bodily matter is, the more efficacious the imagination's power to shape it becomes. For this reason, among all parts of the body, the spiritus is especially susceptible to the influence of the imagination: 'If the motions of the reason and the imagination impress evident signs in both the humors and the solid body', he explains, 'their action is stronger on the spiritus. By means of these signs demons take possession of the contents of men's thinking. ${ }^{39}$ In this respect, Ficino's spiritus is akin to the soul's vehicle, which is also supple and receptive to the action of the images represented by the soul. In the tradition of Neoplatonism, the ochêma was said to act as the mould on which the soul's moral faults were impressed and recorded. The idea that bad behavior can wound the soul probably derives from Plato's Gorgias, in which we read that: 'when a man is stripped of the body, all the natural or acquired affections of the soul are laid open to view' and that, after death, the soul of the wrongdoer 'is marked with the whip, and is full of the prints and scars of perjuries and crimes with which each action has stained him'. ${ }^{40}$ Epictetus expressed a similar idea when he affirmed that the passions of the soul can cause harm to the pneuma. ${ }^{41}$ Porphyry combined these Platonic and Stoic motifs in his view that spiritual bodies acquire the form of the soul's internal representations and that demons can change their external aspect according to their temporary imaginings. ${ }^{42}$ Ficino paraphrased Porphyry's On Abstinence, where this idea was

\footnotetext{
${ }^{38)}$ Ficino, Commentary on Priscianus Lydus's Paraphrase of Theophrastus, in Opera omnia, 1825: 'Imaginatio est tanquam Protheus, vel Cameleon'.

39) Ibid. 'Si motus rationis et imaginationis faciunt manifesta signa in humoribus atque corpora solido, multo magis in spiritum, per haec nota quod daemones cogitationes hominum deprehendunt.'

40) Plato, Gorgias, 524 b-e, tr. by B. Jowett (2006).

41) Epictetus, Dissertationes, II 18.11.

42) See Porphyry, Ad Gaurum, VI, 6-11 and XI.3, De abstinentia 2.42.
} 
clearly expressed. ${ }^{43}$ Iamblichus, whom he translated and adapted in 1497, spoke of imprints left on the soul by bodily pleasures. ${ }^{44}$ Synesius had described the vehicle as a pneumatic surface which retained the forms imagined by the soul during its earthly existence and which survived after death as a corporeal substratum containing and representing all these forms ${ }^{45}$ Finally, Psellus, to whom Ficino's demonology owes a great deal, explained the influence of demons on our soul in terms of an analogy in nature between their spiritual bodies and our imaginative pneuma. ${ }^{46}$ This tradition exerted a strong impact on Ficino, and he was very familiar with the idea that the spiritus acted like a wax tablet on which the images perceived by the embodied soul were both impressed and retained. This becomes clear if one looks at his description of the spiritus as the mould on which sensible impressions are imprinted. The spiritus, is acted on (pulsatur) by external objects:

Rather, with their particular qualities or powers or images, they [bodies] strike upon that warm living vapor which is in a sense the knot of the soul and the body and called 'spirit' by the natural philosophers. ${ }^{47}$

This action does not pass unnoticed, but is perceived by the soul. This perception corresponds to sensible impression:

The soul comes into contact with colors through the spirit in the eye, and with sounds through the spirit in the ears, and with other sensations through the other senses, and does so with the particular power which gives it control over bodies and possession of their seeds in its cognitive no less than in its nutritive capacity. ${ }^{48}$

When commenting on Plotinus's discussion of the soul's perceptive activity and the ways in which this is caused, Ficino introduces the various

\footnotetext{
43) See Ficino, Opera omnia, II, 1932-39. On the topic see also the Chaldean Oracles, 144, 146.

44) Iamblichus, De mysteriis, 201.1-5.

45) Synesius, On Dreams, VII.

46) Psellus, De operatione daemonum, 323-332. See Ficino, Opera omnia, II, 939-45.

47) Ficino, $P T$, III.9.5, 57.

48) Ficino, $P T$, III.9.5, 59.
} 
types of spiritus as elements which can both enable and explain the process of gaining knowledge. In Enneads IV.4.23 Plotinus had maintained that in order for the soul to have sensible perception, there must be an intermediate nature between the subject and the object of knowledge, which is not identical to either but akin to both. ${ }^{49}$ In his commentary on the Enneads Ficino associates this intermediate nature with the spiritus:

When the soul is joined with the body, it uses the spiritus as a sort of mediating instrument between itself and external objects, which creates a proportion between the two. By means of this instrument, external qualities and affections turn into a spiritual and pure species, which is close to the soul's nature, so that through this species the soul stirs up the forms of sensible objects which lay hidden within itself. This process of stirring up is sense perception. ${ }^{50}$

To sum up, the presence of the spiritus within the human body had important consequences on a cognitive level: the soul was unable, on its own, to receive information from the external world and to process sensible knowledge. The soul was the source of all corporeal motions: it could move external bodies, but it could not, in turn, be moved by them. ${ }^{51}$ Therefore, in order for sense objects to be first perceived as unified perceptual data and then translated into mental entities, there had to be an intermediary substance, between the outer world and the soul, on which external objects could impress their action. The soul acted on these impressions either by conceiving in itself new spiritual images of sensible objects or by recovering old notions and combining them to make new ones. If we examine Ficino's account of the reception and elaboration of images in his Commentary on Plato's 'Sophist', we see that the vaporous substance on which external impressions are imprinted-the spiritus-corresponds,

\footnotetext{
49) Plotinus, Enneads, IV.4.23.

${ }^{50)}$ Ficino, Commentary on Plotinus in Opera omnia, II, 1744: 'Quando [anima] corpora conjuncta est, spiritu utitur ut instrumento quodam medio inter eam atque externa, proportionem inter utraque faciente, in quo qualitates vel passiones extrinsecus venientes in speciem spiritalem puramque evadunt animaeque propinquam, adeo ut per hanc anima formas excitet sensibilium in se latentes: quae quidem excitatio est sentire.'

${ }^{51)}$ See Ficino, $P T$, III.9.5, 56: 'Quoniam anima multo est praestantior corpore, et quod assidue format aliquid, est formato praestantius, ideo nulla corpora, sive extra nos sint, sive intra, formas vel imagines suas pingunt in anima.' See M. Heitzman (1935), 307.
} 
more or less directly, to the soul's vehicles. Ficino describes how images are projected onto the surface of one vehicle by another-superiorvehicle, in a downward process, moving from the fiery body to the vaporous spirit:

The soul primarily and effectively exercises the imagination in the celestial vehicle and prepares all the senses through the whole vehicle; and through this vehicle as through a seal frequently it impresses images on the second veil; and through the second similarly it fashions the third..$^{2}$

This passage has been analyzed by Michael Allen, who has shown how the imagination operates on three different levels and explained why images are more clear and distinct in the innermost vehicle than in the one made of vapors..$^{53}$ To his account I would add that the undulating process, by means of which images are transmitted from one vehicle to another, can be seen as a succession of waves agitating the surface of the same substance: the spiritus. The three vehicles are, in fact, the spiritus in three different states: fiery, airy and vaporous. Like the ochêma-pneuma of Synesius, the spiritus can be more or less pure from material affections: as translucent as a mirror or as opaque as moisture-laden air.

A further aspect of Ficino's spiritus connecting it to the notion of ochêma is that it, too, is the substance of which demonic bodies are composed. In the Neoplatonic tradition, the spiritual bodies of demons and the soul's vehicles were thought to be made of the same matter. The general belief was that while the souls of demons had only the body which corresponded to the region where they lived (the air), human souls acquired a new body for each new part of the cosmos in which they dwelled. In the exceptionally clear and detailed account of the doctrine of the ochêma provided by the seventeenth-century English Neoplatonist

${ }^{52)}$ Ficino, Commentary on Plato's 'Sophist', tr. by M. J. B. Allen in M. J. B. Allen (1989), 272.

53) The reason why the imagination has an outward movement and is exercised more effectively in the fiery vehicle is rooted in Ficino's metaphysics, in which perfection means activity and what is less perfect cannot act upon what is more perfect and occupies a higher place in the hierarchy of being. Every action - whether the life given by the power of the soul, an act of knowledge or the perception of an image-must necessarily proceed from above. See Ficino, PT, V.16.1, 229-232. See M. Heitzman (1935), 297. 
Ralph Cudworth in his The True Intellectual System of The Universe, we read that: "There is hardly any other difference left betwixt demons or angels, and men, according to these philosophers [ancient Platonists], but only this, that the former are lapsable into aerial bodies only, and no further; but the latter into terrestrial also. ${ }^{54}$ Moreover, Middle Platonists generally agreed that the souls of good men became demons after death. ${ }^{55}$ Ficino also seems to accept this idea: he describes the soul's vaporous body as the demonic substance by means of which human beings somehow become demons. While commenting on Plotinus's discussion of the nature of demons in Enneads III.4.5, Ficino explains that there are five kinds of demonic bodies: first, bodies made of pure fire such as the stars and celestial demons; second, bodies composed of fire and air thoroughly mixed together; third, bodies made of fire, air and distilled water, which belong to water-laden demons and can even become visible when very damp; fourth, bodies of subterranean demons, which are formed by fire, air, distilled water and a kind of earthly vapor (quasi quidam terrae vapor) $; 5^{6}$ and fifth, the bodies of men:

54) R. Cudworth (1820), III, 528 . See Porphyry, De abstinentia, II.33.

55) See Calcidius's Commentary on Demons, in J. Den Boeft (1977), 47: 'Many philosophers belonging to the Platonic school nevertheless think that demons are souls freed from their bodily task, those of the praiseworthy men the ethereal demons, those of the wicked souls the pernicious demons, and that these same souls only in the thousandth year take an earthly body again, and Empedocles in the same manner thinks that these souls become demons of great age; Pythagoras also in his Golden verses says: "When, having laid aside your body, you will proceed as a free person to aether, you will evade the state of man, having become a god of the bountiful aether." ' Note that also the cicadas in the Phaedrus are demons ex-philosophers. See Ficino, In Phaedrum, ed. by M. J. B. Allen (2008), 3·35.1-2. See also M. J. B. Allen (1984), 23-28.

${ }^{56)}$ Ficino, Commentary on Plotinus, in Opera omnia, II, 1715: 'Sunt igitur animalium rationalium quinque genera. Prima sunt, quorum corpora solus est ignis ac si visibilis ignis stellae sunt, quos antiqui deos nominant: si invisibilis, daemones Orpheus igneos, vel coelestes appellat, qui in planetarum circulis stellarum vicem teneant sub planeta duce. Non enim decet ab innumeris animalibus, quae sunt in firmamento, mox ad unicum infra descendere. Secunda quorum corpora sunt ignis, et aer optime mixtus: hos daemones idem aethereos, vel aereos nominat. Sunt et animalia tertia, in quibus ignis et aer cum subtili quadam aqua componitur, quos daemones iam nominat aqueos, qui quandoque paulo densiores facti, aspici possunt. Neque desunt quarta, quae tribus iam dictis subtilem adhibeant terram, quasi quondam terrae vaporem.' 
As with the bodies of the lowest demons, in which there is a demonic mixture of four subtle elements, a mixture of solid elements is added by means of which we are demons; this is the spiritus within us, which, in the first place, lives and feels. That the spiritus, in the first place, lives and feels is clear from the fact that when it is withdrawn from the limbs, sensation and movement immediately cease and so, too, does life. ${ }^{57}$

The spiritus is compared here to an inner demon, which is alive and sensitive within the outer body. Ficino goes on immediately to identify it explicitly with the airy vehicle, which is the subject of perception and which survives for a long time after, though not forever, after the death of the body:

Since what is received earlier and is similar in nature is held onto more firmly, it seems probable that souls of this kind gradually dismiss the later [i.e., outer] bodies, while holding onto for a longer time the earlier [i.e., inner] ones. Those souls who were in a solid body afterwards remain longer in their subtle body where they had wandered together and in which they had been especially sensitive. This body, because of its affinity, yields easily to the soul which is linked to it. The more sublime and simple a body is, the later it seems to be driven away by the soul, but never in the case of the celestial one, since in every nature, what becomes a participant first of all is always a participant..$^{8}$

Since the airy vehicle is implicitly identified with the spiritus, it is clear that the functions it performs during the soul's embodied life are fundamental

57) Ibid.: 'Quasi infimorum daemonum corpora, in quibus praeter daemonicam illam ex quatuor subtilibus mixturam, qua daemones sumus, quae in nobis spiritus est, primoque vivit et sentit, mixtura solidiorum est adiuncta. Spiritum vero primo vivere atque sentire patet ex eo, quod retracto a membris spiritu, mox sensus, et motus membra deferit, ideoque et vita'.

${ }^{58)}$ Ibid.: 'Cum vero quod prius cognatiusque accipitur, firmius teneatur probabile videtur, animas eiusmodi posteriora gradatim dimittere corpora, prioribus interim diutius reservatis: ut quae fuerunt in corpore solido, diutius postea sint in tenui: in quo pariter erant, et in quo potissimum sentiebant, quod et propter cognationem facile cedit animae connectenti. Quod vero sublimius, simpliciusque corpus est, eo tardius videtur ab anima deferendum, coeleste vero nunquam. In omni siquidem genere, quod primo fit particeps, semper est particeps.' 
both to the general health of body and mind and to the acquisition of knowledge.

In the afterlife, the vehicle acquires a new and more powerful role. Sensation has been cut off by corporeal death, so that the imagination encounters no physical obstacle in fashioning its spiritual matter. In this liminal condition between bodily death and rebirth, the soul continues to be connected to its vehicle and to exist in a realm where it becomes what it imagines itself to be-so much so that its vehicle changes its external shape according to the soul's innermost representations. The idea of the vehicle's susceptibility to the content of what is imagined becomes particularly important in Ficino's arguments against the doctrine of the soul's transmigration into animals. In attempting to demonstrate that this doctrine is metaphysically untenable, Ficino refers several times to the soul's airy vehicle and to its relationship with the faculty of the imagination as evidence in support of his claim that souls never abandon their human nature.

\section{Transforming Bodies: the Imagination and the Afterlife of Souls}

Given that Ficino was ordained a priest in 1473 and became a canon of the Florentine cathedral in 1487 , it is hardly surprising that one of the main aims of his philosophy was to show that Platonism and Christianity were in agreement on the real nature of human souls and their fate. As a spokesman of Catholicism, he was often faced with the problem of how to adapt unorthodox Platonic doctrines to the dogmas of the Christian religion. Belief in the transmigration of human souls into the bodies of animals, a theory which was accepted by Plotinus, is one of the 'heretical' doctrines which he had to deal with and which he tried to counter by using the equally unorthodox theory of the ochêma. In Enneads III.4.3, Plotinus maintained that if the vegetative faculty has been operative during the soul's earthly existence, this faculty will make the life of the soul, after bodily death, similar to that of brute animals. ${ }^{59}$ In his commentary on this section of the Enneads, Ficino devotes a section to metempsychosis,

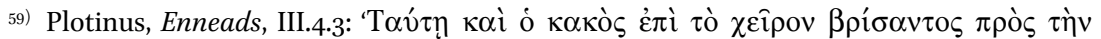

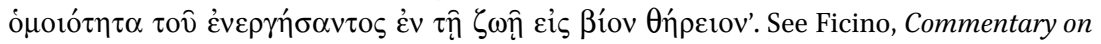
Plotinus, in Opera omnia, II, 1707: 'Si anima vivens ut bestia, fiat denique bestia sensum
} 
entitled: 'On the Transmigration of the Soul and Why It does not Pass into Animals' ${ }^{60}$ His primary goal here is to argue that, although the soul is somehow changed in itself after the death of the body, it never goes beyond the established boundaries of the human species. ${ }^{61}$ Relying on Iamblichus, who said that 'the soul preserves its own species in any transmutation whatsoever, ${ }^{62}$ Ficino explains how this can be ensured by the long-lasting bond between the rational soul and its vehicles:

The soul maintains its human nature everywhere, for it is an earthly, an airy or a heavenly man, as well as a man of the Sun or of Mars. A human being is everywhere the rational soul itself, giving life in a certain way to a body: in heaven, to be sure, it gives life only to a heavenly body; in the region of the air, to an airy body by means of a heavenly body; and, on earth, to an earthly body by means of the other two bodies. ${ }^{63}$

In his arguments against metempsychosis, Ficino uses the theory of the vehicles to ensure that the rational soul can give life and form only to

cum vegetali duntaxat exercens, rationalis huic potestas immine ociosa, et tanquam daemon aliquis observator.'

${ }^{60)}$ Ficino, Commentary on Plotinus, in Opera omnia, II, 1709: 'De transmigratione animae et quod non transit in bestias'. See M. Guyot (2003).

${ }^{61}$ Ibid.: 'Quanquam hominis anima quodammodo in seipsa mutetur nunquam tamen ultra certos humanae speciei terminus transmutatur.'

62) Ibid.: 'Iamblicho placuisse videtur dicenti, animam in qualibet transmutatione suam speciem conservare'. See Nemesius of Emesa, De natura hominis 51.11: 'Cronius, in his work On Reincarnation (for that is the term he uses for transmigration), wants all souls to be rational; and a similar view is advanced by Theodorus the Platonist in his essay entitled "That the Soul is all the Forms," and Porphyry likewise. Iamblichus, however, taking the opposite tack to these, declares that the species of soul corresponds to the species of animal concerned, that is to say, the species of soul are different. At any rate, he composed a monograph entitled "That transmigrations do not take place from men into irrational animals, nor from irrational animals into men, but from animals into animals, and from men into men." Tr. by J. M. Dillon, in J. F. Finamore and J. M. Dillon (2002), 141-42. I would like thank Professor Finamore for drawing my attention to this passage. See also Ficino, Platonic Theology, XVII.4, in Opera omnia, I, 392.

${ }^{63)}$ Ficino, Commentary on Plotinus, in Opera Omnia, 1710: 'Ubique vero [anima] proprietatem conservat humanam. Est enim homo terrenus, est aerius, est et coelestis, est insuper Solaris et Martius: ubique autem homo est ipsa rationalis anima, corpus certo modo vivificans: in coelo quidem coeleste tantum, in aere aerium per coeleste, in terra per utrunque terrenum.' 
human bodies. The vehicles, whether made of flesh, air or heavenly fire, are human bodies in every respect, and an individual person does not cease to exist as such just because he moves from the earth to the region of the air. An airy man is a human being, even without flesh and bones, and the same can be said of a soul informing a heavenly body. His central argument is that, in order to be punished for its earthly sins, the soul does not need to be incarnated again into the body of an animal, since physical suffering is much more real and intense in the body made of air, which the soul continued to inform between its different lives, than in a body made of flesh and blood, whether of a human being or of an animal. This is because in the airy vehicle the influence of the imagination is more powerful and pain is more acute, for it touches the soul almost directly, without the intermediary action of the nerves. Ficino writes: 'The five senses which are exercised in the nerves and spirits emanate from those that flourish in the imagination. But in the imagination these five are one sense: it is more comprehensive than they are and more perspicacious and indeed more stable; for it preserves what they not preserve. ${ }^{64}$ For Ficino, the imagination which survives bodily death in the vehicle is a kind of heightened sense, much more powerful than the five external senses. This is why all the sufferings experienced by the soul on earth are nothing when compared to the severe physical pain the soul experiences after death while living in its vehicle, where the imagination is located. In the airy vehicle, indeed, suffering and pain are much more intense. As a Platonist, Ficino regarded the reality perceived by the senses as less real than the representations of the imagination. Consequently, we are often led to mistake bodiless images of things for the actual things themselves:

It should not appear unbelievable to anyone that all corporeal objects are known through their incorporeal paradigms rather than the reverse. For it is through the spiritual images of sensible objects (imagines sensibilium spiritales), whether they are in the senses or in mirrors, that we perceive sensible bodies, not vice versa. And is it surprising we are so deceived in this matter that when we look at things' spiritual paradigms we often think we are gazing only at their corporeal natures? For children when they see the bodiless images of bodies (simulacra corporum incorporea) in mirrors, and dreamers,

${ }^{64)}$ Ficino, Letters, in Opera omnia, I, 715, tr. by M. J. B. Allen, in Ficino, PT, VI, 267. 
when they peruse spiritual images, both believe they are seeing actual bodies. $^{65}$

Therefore, paradoxical as it may seem, the imagined pain suffered by the airy body is far stronger and much more acute than the physical pain of the earthly body. Ficino describes the impious soul's imaginary hell as follows:

In the impious man there remains, so the Platonists believe, the overlordship either of the raging phantasy alone, or of the phantastical reason. Moved by hate, as I have said, and by fear, this phantasy or phantastical reason busies itself with a long succession of gloomy images. The impious man now sees the heavens crashing on his head or himself being swallowed up in the deep fissures of the earth, next being taken up by the force of flames, and then submerged in a vast whirlpool of waters or encircled by the shades of daemons. Thus, he drives his body on everywhere through the depths wherever the impulse of the raging phantasy and the bad daemon will have swept it away, as Mercurius says (and Plato too). ${ }^{66}$

But, how can the vehicles be involved in the creation of such a terrible imaginary hell? According to Ficino, the celestial and airy vehicles survive the disintegration of the earthly body, as do their faculties, reason and the imagination. When the action of the five senses ceases after death, these surviving faculties are intensified: if someone is accustomed chiefly to using reason, after death he will speculate with the greatest diligence; if, by contrast, someone is in the habit of employing his imagination, he will imagine with the greatest fervor. This, Ficino explains, happens in sleep to such an extent that we are led to believe that images of things are truly the things themselves and, terrified by these sights, we sweat and cry out until we wake up. ${ }^{67}$

\footnotetext{
65) Ficino, $P T$, IV.12.1, 15-16.

66) Ficino, PT, VI.18.10, 197. See Hermes Trismegistus, Asclepius 28; Plato Phaedo 107D-108C, $112 \mathrm{~A}-114 \mathrm{~B}$.

${ }^{67)}$ See Ficino, PT, VI.18.10, 196: 'Id usque adeo fit in somno ut quae rerum imagines sunt res veras esse putemus atque horribilibus visis perterriti trepidemus, sudemus, vociferemur atque surgamus. Multo magis impiis in morte atque post mortem fallacia terribilium contingit imaginum'.
} 
When ancient philosophers described souls being implanted in the bodies of animals after death, they were referring to their depraved imagination, which, following the dissolution of the body, acquires such an unrestrained power that it mistakes its own representations for real things and blurs the boundaries of 'reality' and 'unreality'. The imagination of a person who has kept his soul far from the intellect and close to the life of animals, will after death amplify the images with which that soul has been most familiar. In this way, he will be besieged and obsessed by what his imagination sees or imagines that it sees, until he ends up believing that he really posses an animal body. That is what happened to Nebuchadnezzar, the king of the Babylonian empire, who, according to the Bible, was reduced to an animal madness and to eating 'grass as oxen':

When the prophet Daniel says that the king of Babylon, on account of his terrible crimes, was transported by divine agency among the oxen until, purified, he felt respect, the Hebrews interpret this to mean that the imagination of that king was so distraught by divine agency that he believed himself to be an ox and suffered grievously, as usually happens when we are afflicted by a magician or by melancholy [is apt to bring about].$^{68}$

The vehicle enables the representations of the imagination to become, as it were, real; and it is especially important because it is the instrument of the soul's imaginary self-tortures. It can also, however, be the instrument of its atonement, for in the airy body the soul is not distracted by the activity of the senses and, therefore, is less sensitive to the appeal of material things. That is why, while dwelling in the vehicle, the soul not only suffers to the highest degree, but is also better able to ascend to the higher levels of reality and to reunite with the Intellect.

We should, therefore, follow Timaeus of Locri's opinion that, soon after death, the soul which has fallen into a perverse reasoning and a more lively imagination because of its sins will be tortured in its airy body (which it

\footnotetext{
68) Ficino, Commentary on Plotinus, in Opera omnia, II, 1711: 'Nam ubi Daniel propheta tradit Babyloniae regem ob gravissima scelera,inter boves divinitus fuisse translatum, donec purgatus respiceret: interpretantur Hebraei imaginationem Regis illius divinitus fuisse perversam, usque adeo, ut bovem se factum opinaretur, graviterque doleret; quemadmodum solet Magus, vel atra bilis efficere.' See Daniel 5:21.
} 
already possesses) by that same perversion of reasoning and liveliness of the imagination. It will dwell among the lowest demons, which will prick it with the same kind of stings. These sufferings will last until the soul realizes that a great torment has been caused by this turning away from the Intellect; and, gradually, it will return to the Intellect, which it can now perceive more distinctly than before, since there are fewer distractions. ${ }^{69}$

For Ficino, the connection between the soul and its vehicles provided evidence against those who asserted that the rational soul could lose its genuine nature and sink downwards to the level of an animal. In his Commentary on Plotinus, this argument is used to show that the position expounded in Enneads III.4.3 was untenable. Moreover, the permanent connection between the soul and its vehicles ensured another important truth: that, in its afterlife, the soul retains its psychological features and, therefore, its personal identity: 'After its life on earth, the soul awakens and recovers its previous status, so that, throughout the centuries, which are like the different ages of a single life, the personality of the rational soul remains the same. ${ }^{70}$ Since our personal identity is intimately connected not only to the content of our imagination and reason but also, and especially, to our remembrances, there had to be another faculty which, according to Ficino, survived the death of the body and was transported into the heavens by the vehicles. This faculty was memory.

\section{The Vehicles of the Soul and Memory in the Afterlife}

The role of the vehicle in bearing within itself the imaginative faculty and the irrational soul implied that our inherent characteristics are not lost when our body dies, but instead remain in the vehicle, awaiting the return

${ }^{69)}$ Ibid., II, 1710: 'Oportet igitur ex Timaei sententia dicere, hominis animam, quae peccando in rationem perversam imaginationemque vehementiorem prolapsa est, post obitum mox in aerio corpore, quod nunc etiam possidet, eadem ipsa cogitationis perversitate vehementiaque torqueri inter infimos daemones, similibus animam stimulis subpungentes, quousque tantae angustiae causam recognoscens fuisse aversionem ipsam ab intellectu, paulatim revertatur ad ipsum: quod tunc per pauciora distracta planius, quam nunc animadvertere potest.' See Timaues of Locri, 84-86.

${ }^{70)}$ Ibid., 1711: 'Supra terram evigilare, pristinumque sui statum animadvertere: ut per omnia secula, quasi vitae unius aetates rationalis animi persona sit eadem.' 
of our rational soul. The imaginative faculty and the irrational soul are reborn, together with the rational soul and the vehicle, as each new life begins. The soul keeps its innermost images throughout its different lives, and these images persist in each rebirth. Moreover, it would be possible, according to Ficino, for us to use them to recall our past lives. Plotinus connects memory very closely to the imagination: 'To remember is to think or to imagine. To imagine in itself does not consist in possessing something, but in becoming similar to what is seen. ${ }^{71}$ In commenting on this passage, as we shall see, Ficino points out that memories can survive as long as the reason and the imagination continue to exist, that is, as long as these two faculties are carried in the soul's vehicle.

In Book 4 of the fourth Ennead, Plotinus discusses how, after death, the soul forgets the experiences of its life on earth, as its proceeds towards the intelligible world..$^{2}$ Ficino equates this loss of memory with the loss of the soul's vehicle and of the forms in its imagination. A complete absence of memories will be experienced by the soul only when it removes its final body, the ethereal vehicle, and stands naked in front of the Intellect. Ficino writes: 'Once the soul has taken off its ethereal body and is shaped by the divine Intellect, it contemplates everything divine very intently and at once, without using discursive reason, and is said not to remember human things. ${ }^{73}$ At this stage, according to Plotinus, the soul is totally free from the memories of its past life, to such an extent that it does not even recognize itself as an individual soul or intellect-as, for instance, Socrates's soul. ${ }^{74}$ Plotinus did not believe, of course, that the soul was unaware of all the events which happened during its earthly life, for in the intelligible world it continued to know what it had done and what it had been on earth. Nevertheless, while, before reaching the Nous, the soul

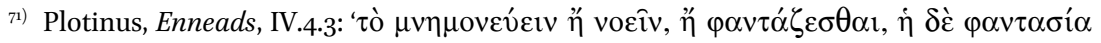

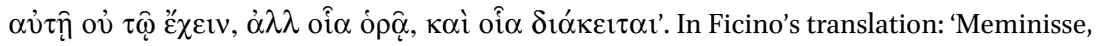
vel intelligere vel imaginari. Haec autem ipsa imaginatio non in eo consistit, quod habeat aliquid, sed quod videat disponaturque'. See Plotinus, Enneades cum Marsilii Ficini interpretatione castigata (1855), 223.

72) Plotinus, Enneads IV.4.1.

73) Ficino, Commentary on Plotinus, in Opera omnia, II, 1740: 'Anima corpus omne vel coeleste quandoque exuta, et mente divina tunc formata attentissime divina conspicit simul cuncta sine discursu, ideo dicitur non recordari rerum humanarum.'

74) Plotinus, Enneads IV.4.2. 
remembered itself as Socrates and as having lived in Athens, once it reached the intelligible world, it was still aware of these things, but without remembering them. When the soul reaches the Nous, Plotinus explains, there is only contemplation, and contemplation is timeless: the soul knows all things at once in an eternal present. ${ }^{75}$ It neither remembers the past nor foresees the future: it simply knows all past and future events.

According to Ficino, the soul's ascent to this kind of knowledge, without memories, is achieved gradually, through the soul's progressive stripping off of all its bodies, so that it neglects material life and concentrates on divine things:

In both our rational and irrational souls, the memory of human things remains. In the lower soul, however, memories are confused, especially if it does not completely obey the higher soul. By contrast, the higher soul remembers things without confusion, especially if it does not pay much attention to such memories. Likewise, in the airy body, we remember a great many events belonging to our earthly life, in the celestial body only a few memories and, above heaven, very few indeed. The soul remembers few things there, not because of the weakness of memory, but because it directs its attention to better things and disregards worse ones, except to the extent that it gazes at the latter through the former. ${ }^{76}$

Ficino's idea is that, until reason and the imagination are cut off by the loss of the last vehicle, the soul retains a more or less accurate memory of its past doings. Once the soul abandons its innermost body, however, it is no longer able to recognize itself as an individual: along with its vehicle, the soul loses the products of its imagination, its psychological features and all of its memories. For Ficino, it is at the moment when the soul becomes forgetful of itself as an individual person, described by Plotinus

\footnotetext{
75) Plotinus, Enneads IV.4.1. 20.

${ }^{76)}$ Ficino, Commentary on Plotinus, in Opera omnia, II, 1740: 'In utraque anima post obitum, humanorum memoria remanet, sed inferiore, cum perturbatione, praesertim quando superiori non prorsus obtemperavit. In superiore vero sine perturbatione, praesertim quando talia paruipenderit. Item in corpore aerio reminiscimur mortalium quamplurimorum, in coelesti pauciorum, extra coeli paucissimorum. Recordari vero illic pauciorum non provenit ex debilitate memoriae, sed ex attentione circa meliora, negligente deteriora, nisi quatenus haec per illa conspiciuntur.'
} 
in the fourth Ennead, that it is completely naked. This loss is not, however, irrecoverable: when, after living in the intelligible world, the soul's affection for the realm of generation once again becomes dominant and the soul once again joins itself to a celestial body, memories are gradually recovered:

The soul eventually descends into its celestial body when it unfolds itself into its multiplicity, now acting according to the intellect, reason and the imagination. At this moment, the soul now almost (ferme) remembers itself and the events of its past life, as it used to do when it lived among human beings, that is, through the movement of reason, even though it is extremely swift there, and through the shapes and images (formationes atque simulachra) of the imagination. ${ }^{77}$

Not only do the vehicles help the soul to recall its past lives, they can also serve as instruments to arouse the memory of other souls. By seeing the shape, color, movement and brightness of the aerial bodies of other souls, we can recognize our old friends and remember the events of our own past existence. Ficino describes a sort of social environment in which the after-death soul, wrapped in their airy bodies, take part:

In heaven souls recognize each other, especially friends and former acquaintances, either because of the movements and lively passions of their souls, or by means of their spiritual bodies, which there can have a similar shape in limpid matter, which yields more to any fashioning action of the soul than earthly matter does now to its affections. Here, although all bodies are spherical, there will be different signs and indications of different souls in indifferent things, either in shape, as we said, or in size, quality, a motion, a gesture, a nod, a glitter-as happens in one's eyes due to the emotions of the soul and in the different shapes and colors of various clouds. There are those who believe that heavenly souls emit sounds and that the heavens are filled with

77) Ibid.: 'Descendit tandem in corpus coeleste, quando suam ipsam in se explicat multitudinem, agens iam videlicet per intellectum, rationem, imaginationem: tunc et sui rerumque suarum ita ferme iam reminiscitur, quemadmodum apud homines consueverat, scilicet quam per rationis agitationem, quamvis ibi celerrimam, tum per imaginationis formationes, atque simulachra.' 
their voices or at any rate that they communicate with each other by means of nods. ${ }^{78}$

As is apparent in this passage, the role of the vehicles is particularly important in the afterlife. The vehicles, once they are freed from their earthly envelope, not only display the soul's temporary dispositions-its cheerful or gloomy moods-but also reflect its inherent nature in the most faithful way, to such an extent that one can unmistakably recognize one's friends merely by the shape or the light of the aerial bodies of their souls. In other words, while living in the earthly body one can easily keep one's real personality hidden from others; in the aerial body, by contrast, one's true self is laid open. Here, too, Ficino seems to have used the vehicles implicitly to support his general claim for the personal immortality of the soul.

\section{Conclusion}

Ficino was well aware that, according to the teachings of Christian religion, the soul was created by God out of nothing in the moment when it joined the body. Nevertheless, the idea of different semi-material vehicles enveloping the soul before, during and after its life on earth apparently appealed to him. He certainly used it as evidence for his claim that, after the death of the body, souls continued to exist as individuals. The threat represented by the Averroist account of the soul unquestionably influenced his efforts to prove that corporeal death does not destroy individual identity and that souls inhabit heaven or hell in a very 'personal' way. In order to understand the role played by the vehicles in Ficino's defense of

\footnotetext{
${ }^{78)}$ Ibid.: 'Agnoscunt igitur in caelo se invicem animi, amici praesertim atque quondam noti, cum per ipsos motus affectusque vividos animorum, tum per corpora, quae ibi habere possunt figuram hujusmodi similem in materia liquida, cedente multo magis animo quomodocumque formatori, quam terrena materia nunc affectibus animae. Tum vero, si corpora illic orbicularia sint, differentia tamen erunt indifferentibus signa indiciaque differentium animorum, sive in figura, ut diximus, sive magnitudine, qualitate, motu, gestu, nutu, luce, quemadmodum fit in oculis ex affectibus animorum, et in variis nubibus figurae differentes atque colores. Sunt qui velint, caelicolas inter se voces edere, nam et caelos posse sonare, saltem vero mutuis inter se nutibus colloquentur.'
} 
individual immortality, it is useful to consider a passage in the Platonic Theology where he claims, against Averroes's contention that there is only one rational soul for all mankind, that different souls have different ways of intuiting divinity. ${ }^{79}$ In Ficino's view, however, the intellect, although it was the most important faculty of the soul, which made it akin to the Ideas, was not sufficient to justify personal immortality. In other words, the survival of the individual intellect alone represented a kind of 'incomplete' immortality. For this reason, Ficino turned to the vehicles to explain the persistence of the person as whole, a concept which included both the higher and the lower faculties of the soul. In the passage just cited, he points out that individual differences between souls concern not only 'gazing upon things eternal', but also 'governing things temporal' ${ }^{80}$ The vehicles, in this context, ensured the persistence of two powers which were deeply involved in the constitution of personal identity: the imagination and memory. In the Platonic Theology he explained that the action of the imagination, which enabled the soul to ascend from material to eternal things, was still exercised in the vehicle even when the action of the five senses ceased. Moreover, Plotinus's speculations on memory, as found in Enneads IV.4, gave Ficino the occasion to claim that this faculty also survived, as long as it was carried in the universe by the vehicle. Precisely by emphasizing that the vehicles carried the soul's lower powers after bodily death, Ficino was able to back up his contention that souls survived death as individual persons. He did not appeal to the doctrine of the vehicles explicitly to counter the Averroist doctrine of the soul; however, his assumption that a kind of after-death embodiment permitted the survival of both the contents of one's imagination and one's memories implied that the irrational part of the soul survived along with the intellect and the will. Therefore, for Ficino, the soul continued to live as an integral whole and to maintain its personal identity throughout the centuries, as he explicitly stated in his Commentary on Plotinus. $^{81}$

If Ficino was always very cautious in establishing a direct connection between the vehicles of the soul and individual immortality, the

\footnotetext{
79) Ficino, PT, V.15.13, 150.

80) Ibid.

${ }^{81)}$ See earlier, 20.
} 
seventeenth-century heirs of his brand of Christian Platonism, the Cambridge Platonists Ralph Cudworth and Henry More, dealt with the topic much more boldly. Henry More, in particular, established an explicit connection between the vehicles and the afterlife of individual souls, showing that the soul's consciousness and its ability to respond to external stimuli did not depend on the external organs, but instead on the vehicle. This view is fully developed in More's Antipsychopannychia, a philosophical poem which sought to criticize the mortalist position, according to which, after death, the soul enters a state of insensibility and somnolence, similar to death, which would end with God's final judgment on the last day. This theory, very common among Protestants, was also known as 'psychopannychism' or the 'sleep of the soul'. More's claimed that since the vehicle was the immediate seat of life and survived physical death, the soul could neither be said to die with the body nor to become insensible. While dwelling in its vehicle, the soul continued to be sensitive and to be capable both of perceiving images and of feeling pleasure and pain. More's position undoubtedly drew on Ficino's speculations about the soul's vehicles as the carriers of the soul's lower faculties during both its earthly existence and its afterlife. Similarly, Ralph Cudworth's opinion that 'there could not be then so much as phantastick punishment neither, nor any imagination at all in souls, without a body', ${ }^{82}$ owes a good deal to Ficino's discussion of the vehicles as the seat of imaginative punishments after death.

Ficino himself may have deliberately left his account of the vehicles in the background, but the influence it exerted on later authors such as More and Cudworth indicates that this doctrine had a central part to play among Christian Platonists of the Renaissance and early modern era in the defense of individual immortality. The Neoplatonic doctrine of the vehicles provided a philosophical justification for the preservation of the unity of the soul throughout the centuries, for it showed that not only did the intellect and will survive physical death, but that the irrational part of the soul, including the imagination and memory, also continued to exist in the universe, carried in the vehicle.

82) R. Cudworth (1995), III, 383 . 


\section{Bibliography}

\section{Primary Sources}

Alexander of Aphrodisias, Pseudo-. 1841. Problemata medica (ed. Ideler).

Aristotle. 1943. De generatione animalium, translation by A. L. Peck. Cambridge (Mass.): Harvard University Press.

Cudworth, R. 1995. The True Intellectual System of the Universe. 3 vols. Bristol: Thoemmes Press (reprint of the 1845 edition).

Epictetus. 1758. All the works of Epictetus, which are now extant; consisting of his Discourses, preserved by Arrian, in four books, the Enchiridion, and fragments, translation by E. Carter, London: Richardson.

Ficino, M. 1576. Opera omnia, 2 vols., Basel: Heinrich Petri (repr. Turin: Bottega d'Erasmo 1962).

- 2001/2006. Platonic Theology, edited by M. J. B. Allen, J. Hankins and W. Bowen, 6 vols., Cambridge (Mass.) and London: I Tatti Renaissance Library.

- 2008. In Phaedrum, in Marsilio Ficino's Commentaries on Plato. Phaedrus and Ion, edited and translated by M. J. B. Allen, Cambridge (Mass.): I Tatti Renaissance Library, 38-193.

Galen. 1538. De placitis Hippocratis et Platonis, in Galen, Opera omnia, Basel: Par'Andrea to Kratandro.

Iamblichus. 1973. In Platonis Dialogos Commentariorum Fragmenta. Edited with translation and commentary by J. M. Dillon, Leiden: Brill.

- 2002. De anima. Text, translation and commentary by J. F. Finamore and J. M. Dillon, Leiden: Brill.

-2003. De mysteriis, Translated with an introduction and notes by E. C. Clarke, J. M. Dillon and J. P. Hershbell, Atlanta: Society for Biblical Literature.

Plato. 2006. Gorgias, Translation by B. Jowett, Teddington: Echo Library.

Pletho. 1995. Oracles Chaldaïques. Recension de Georges Gémiste Pléthon, introduction, translation and commentary by B. Tambrun-Krasker, Athens-Paris-Brussels: The Academy of Athens-J. Vrin-Ousia.

Plotinus. 1855. Enneades cum Marsilii Ficini interpretatione castigata, Paris: Didot.

— 1966-88. Enneads, transl. by A.H. Armstrong, 6 vols, London and Cambridge (Mass.): Harvard University Press.

Porphyry. 1895. Ad Gaurum, Berlin: K. Kalbfleisch.

—. 1979-1995. De abstinentia ab esu animalium, in J. Bouffartigue, M. Patillon, and A. P. Segonds (eds.), 3 vols., Paris: Budé.

Porphyry. 1895. Ad Gaurum, edited by K. Kalbfleisch. Abhandlungen der Preussischen Akadamie der Wissenschaft. phil.-hist. kl., 33-62.

Proclus. 1993. Elements of Theology edited by E. R. Dodds, Oxford: Clarendon.

Psellus. 1964. De operatione daemonum, Amsterdam: A. M. Hakkert (reprint of the edition Nürmberg, 1838).

Synesius. 1576. On Dreams, in M. Ficino, Opera omnia, 2 vols, Basel (reprint Turin, 1962), II, 1968-1978. 
Timaeus of Locris. 1985. On the Nature of the World and the Soul, text, translation and notes by T. H. Tobin, Chico (Cal.): Scholars Press.

\section{Secondary Literature}

Allbutt, C. 1921. Greek Medicine in Rome, London: Macmillan.

Allen, M. J. B. 1982. 'Ficino's Theory of the Five Substances and the Neoplatonists' Parmenides'. Journal of Medieval and Renaissance Studies, 12, 19-44.

—. 1981. Marsilio Ficino and the Phaedran Charioteer, Berkeley, Los Angeles and London: University of California Press.

— 1984. The Platonism of Marsilio Ficino: A Study of his "Phaedrus" Commentary, its Sources and Genesis, Berkeley and London: University of California Press.

—. 1989. Icastes: Marsilio Ficino's Interpretation of Plato's Sophist. Five Studies and a Critical edition with Translation, Berkeley-Los Angeles-Oxford: University of California Press.

— 1995. "Summoning Plotinus: 'Ficino, Smoke and the Strangled Chickens" in Plato's Third Eye. Studies in Marsilio Ficino's Metaphysics and its Sources, Aldershot: Variorum, 63-88.

—. 2002. 'Life as a Dead Platonist', in M. J. B. Allen and V. Rees, with M. Davies (eds.), Marsilio Ficino: His Theology, His Philosophy, His Legacy, Brill's Studies in Intellectual History, vol. 108, Leiden: E. J. Brill, 159-178.

—. 2008a. 'Quisque in sphaera sua: Plato's Statesman, Marsilio Ficino's Platonic Theology and the Resurrection of the Body'. Rinascimento, 2nd ser., 47, 25-48.

—. 2008b. 'At Variance: Marsilio Ficino, Platonism and Heresy', in D. Headley and S. Hutton (eds.), Platonism at the Origins of Modernity: Studies on Platonism and Early Modern Philosophy, International Archives of the History of Ideas / Archives internatio nales d'histoire des idées, Vol. 196, Dordrecht: Springer, 31-44.

—. 2010. 'Marsilio Ficino on Saturn, the Plotinian mind, and the monster of Averroes'. Bruniana e campanelliana, 16/1, 11-29.

Barker, P. 1991. "Stoic Contributions to Early Modern Science," in M. J. Osler (ed.), Atoms, Pneuma and Tranquillity: Epicurean and Stoic Themes in European Thought. Cambridge (Mass.): Cambridge University Press, 135-154.

Bidez, J. 1964. Vie de Porphyre, 2nd ed., Hildesheim: Olms.

Coccia, E. 2005. La trasparenza delle immagini: Averroè e l'averroismo, Milan: Mondadori.

Copenhaver, B. P. 1987. 'Iamblichus, Synesius and the Chaldean Oracles in Marsilio Ficino's De Vita Libri Tres: Hermetic magic or Neoplatonic Magic?', in J. Hankins, J. Monfasani and F. Purnell, Jr., (eds.), Supplementum Festivum: Studies in Honor of Paul Oskar Kristeller, Binghamton, NY: MRTS, 441-455.

_. 2009. 'Ten Arguments in Search of a Philosopher: Averroes and Aquinas in Ficino's Platonic Theology'. Vivarium 47/4, 444-479.

Coulianu, I. 1981. 'Magia spirituale e magia demonica nel Rinascimento'. Rivista di storia e letteratura religiosa, 17, 360-408. 
Di Pasquale Barbanti, M. 1988. Ochêma-pneuma e phantasia nel Neoplatonismo. Aspetti psicologici e prospettive religiose, Catania: CUECM.

Den Boeft, J. 1977. Calcidius on Demons. Commentarius ch. 127-136. Leiden: Brill.

Finamore, J. F. 1985. Iamblichus and the Theory of the Vehicle of the Soul, Chico (Cal.): Scholars Press.

Grendler, P. F. 2004. The Universities of Italian Renaissance, Baltimore: The Johns Hopkins University Press.

Guyot, M. 2003. 'Marsile Ficin, Commentaire sur du traité de Plotin sur le "demon qui nous a reçu en partage" ' in J. Laurent (ed.), Les diuex de Platon, Caen: Presses universitaires de Caen, 263-286.

Hankins, J. 2005., 'Marsilio Ficino on Reminiscentia and the Transmigration of Souls'. Rinascimento 45, 3-17.

—. 1994. 'Lorenzo de' Medici as Patron of Philosophy'. Rinascimento 34, 15-53.

Heitzman, M. 1935 and 1936. 'L'agostinismo avicennizante e il punto di partenza della filosofia di M. Ficino', Giornale Critico della Filosofia Italiana 16, 295-322; 460-480; 17, 1-11.

Iorio, D. 1991. The Aristotelians of Renaissance Italy: a philosophical exposition, Lewiston, NY: Mellen.

Joly, B. 1993. 'Présence des concepts de la physique Stoïcienne dans les textes alchimiques du XVII siècle' in J. C. Margolin and S. Matton (eds.), Alchimie et philosophie à la Renaissance, Paris: Vrin, 341-354.

Kissling, R. C. 1922. 'The ochêma-pneuma of the Neo-Platonists and the De Insomniis of Synesius of Cyrene'. American Journal of Philology 43, 318-330.

Klein, R. 1956. 'L' Imagination comme vêtement de l' âme chez Marsile Ficin et Giordano Bruno". Revue de Métaphysique et de Morale, 61, 18-38.

—. (1960), "L' Enfer de Ficin" in E. Castelli (ed.) Umanesimo e esoterismo, Padua: CEDAM.

Klutstein, I. 1986. 'Marsile Ficin et les Oracles chaldä̈ques', in Garfagnini, G. C. (ed.) Marsilio Ficino e il ritorno di Platone : studi e documenti. 2 vols, Firenze: L. S. Olschki, I, 331-338.

Kraye, J. 2004. 'Stoicism in the Renaissance from Petrarch to Lipsius' in H. W. Blom and L. C. Winkel (eds.), Grotius and The Stoa, 21-45.

Kristeller, P. O. 1965. Renaissance Thought II, New York: Harper \& Row.

—. 1986. 'Marsilio Ficino and His Work After Five Hundred Years' in Garfagnini, G. C. (ed.), Marsilio Ficino e il ritorno di Platone: studi e documenti. 2 vols., Florence: L.S. Olschki, II, 15-196.

—. 1988. Il pensiero filosofico di Marsilio Ficino, Florence: Le Lettere.

Ogren, B. 2004. 'Circularity, the Soul-Vehicle and the Renaissance Rebirth of Reincarnation: Marsilio Ficino and Isaac Abarbanel on the Possibility of Transmigration'. Accademia 6, 63-94.

Saffrey, H. D. 1996. 'Florence, 1492: The Reappearance of Plotinus'. Renaissance Quarterly, 49, 488-508.

Smith, A. 1974. Porphyry's Place in the Neoplatonic Tradition. A Study in Post-Plotinian Neoplatonism, The Hague: Martinus Nijhoff. 
Tambrun, B. 'Marsile Ficin et le Commentaire de Pléthon sue les Oracles Chaldaïques'. Accademia 1, 9-48.

Toussaint, S. 2007. "Sensus naturae”. Jean Pic, Le véhicule de l' âme et l' équivoque de la magie naturelle"' in F. Meroi and E. Scapparone (eds.), La magia nell'Europa moderna. Tra sapienza antica e filosofia naturale, 3 vols, Florence: Leo S. Olschki, I, 107-145.

Verbeke, G. 1945. L' evolution de la doctrine du pneuma du stoicisme à s. Augustin, Paris: Desclée de Brouwer.

Walker, D. P. 1958. Spiritual and Demonic Magic from Ficino to Campanella, London: Warburg Institute.

— 1984. 'Medical Spirits and God and the Soul' in M. Fattori and M. Bianchi (eds.), Spiritus. IV Colloquio internazionale del Lessico intellettuale europeo, Rome: Edizioni dell' Ateneo, 233-244.

Wolters, A. M. 1986. 'The First Draft of Ficino's Translation of Plotinus', in Garfagnini, G. C. (ed.) Marsilio Ficino e il ritorno di Platone: studi e documenti. 2 vols, Florence: L. S. Olschki, I, 305-329. 